J. Dairy Sci. 99:9395-9404

http://dx.doi.org/10.3168/jds.2016-11499

(C) 2016, THE AUTHORS. Published by FASS and Elsevier Inc. on behalf

of the American Dairy Science Association ${ }^{\circledR}$. This is an open access article under

the CC BY-NC-ND license (http://creativecommons.org/licenses/by-nc-nd/3.0/).

\title{
Immune-modulating properties of horse milk administered to mice sensitized to cow milk
}

\author{
J. Fotschki, ${ }^{*}$ A. M. Szyc, ${ }^{*}$ J. M. Laparra, $†$ L. H. Markiewicz, ${ }^{*}$ and B. Wróblewska* \\ *Department of Immunology and Food Microbiology, Institute of Animal Reproduction and Food Research, Polish Academy of Sciences, \\ Tuwima 10, 10-748 Olsztyn, Poland \\ †Immunonutrition and Health Group, Valencian International University, C/Gorgos 5-7, 46021 Valencia, Spain
}

\begin{abstract}
The aim of this study was to examine immune adaptive changes, the expression of innate biomarkers and variations in intestinal microbiota composition after horse-milk administration in BALB/c mice, which were sensitized intraperitoneally using cow $\beta$-lactoglobulin and $\alpha$-casein with aluminum adjuvant. We measured serum antibody $\operatorname{IgE}$ levels and the expression of $M C P$ 1, IL-4, and TNF- $\alpha$ in duodenal samples. Changes in immune cell populations in peripheral blood were quantified using flow cytometry, and intestinal microbiota composition was assessed using real-time PCR. We found that horse-milk administration decreased serum $\operatorname{IgE}$ levels in sensitized mice. The groups that received horse milk showed an increased population of regulatory $\mathrm{T}$ cells $\left(\mathrm{CD} 4^{+} \mathrm{Foxp}^{+}\right)$. Horse-milk administration decreased the mRNA levels of $I L-4$ and resulted in higher transcripts of $T L R-4$ in all treatment groups; however, the levels of $M C P-1, T N F-\alpha$, and $T L R-2$ were unaltered. After horse-milk treatment, we observed a positive effect, with increased numbers of intestinal Bifidobacterium spp. We observed immune-modulating properties of horse milk, but future studies should focus on testing horse-milk processing, such as fermentation and destroying most allergenic epitopes to continue research under clinical conditions.
\end{abstract}

Key words: mare milk, equine milk, BALB/c mice, cow milk protein allergy

\section{INTRODUCTION}

The increasing incidence of cow milk allergy highlights the need to develop novel functional foods adapted to allergic consumers. An allergy to cow milk proteins results from an adverse immunological reaction to 1 or more of those proteins. Due to the low homol-

Received May 23, 2016.

Accepted September 1, 2016.

${ }^{1}$ Corresponding author: b.wroblewska@pan.olsztyn.pl ogy between cow- and horse-milk proteins, horse milk could be a potential candidate for a health-promoting formula with decreased immunoreactivity and higher nutritional value than formulas based on plant materials.

The proportions of subjects with a high sensitivity to the different cow milk proteins have been estimated: $55 \% \alpha_{\mathrm{S} 1}$-casein, $90 \% \alpha_{\mathrm{S} 2}$-casein, $45 \% \beta$-lactoglobulin, and $0 \% \alpha$-lactalbumin [demonstrated by oral provocation tests, radioallergosorbent test (CAP-RAST, Pharmacia \& Upjohn Diagnostics AB, Uppsala, Sweden), and skin prick tests; Natale et al., 2004]. The probability of cross-reactivity between cow milk proteins and those of other animal species has been studied, and it has been shown that $\operatorname{IgE}$ from the sera of children allergic to cow milk are capable of recognizing defined epitopes of milk proteins from other animals, such as ewe, goat, and buffalo (Restani et al., 2002). These data demonstrate that milk protein polymorphisms can provoke immunogenic reactions of differing severity and cross-reactivity (Restani et al., 2002; El-Agamy, 2007). Previous research efforts have revealed that antibodies ( $\operatorname{IgG}$ ) directed at cow milk proteins do exhibit cross-reactivity with horse-milk proteins (Fotschki et al., 2015a). However, cross-reactivity between equine and bovine milk proteins occurs at a low level (Businco et al., 2000), probably due to differences between the amino acid sequences (Karabus and du Toit, 2012). Additionally, horse milk has biophysical and biochemical properties that place it closer to human milk than cow milk (Nikkhah, 2012). Its similar total protein content and optimal casein/whey protein ratio, which may be an important factor in determining its allergenicity and richness in essential nutrients (Lara-Villoslada et al., 2005; Fiocchi et al., 2010), supports the potential of using horse milk as a substitute for breast milk. This might be particularly important in certain scenarios to fulfill the nutritional requirements of infants with high sensitivity to cow milk proteins. In line with these studies, recent in vitro data have estimated lower uptake rates of proteolytically resistant peptides from horse 
milk with respect to cow milk, suggesting a potential beneficial role for horse milk in the human diet (Fotschki et al., 2015b). Nevertheless, few attempts have been made to evaluate potential allergic responses to horse-milk proteins. Studies have focused only on the tolerance and allergic potential of horse milk in children with a cow milk allergy (Businco et al., 2000; Fiocchi et al., 2010), and these studies have demonstrated good tolerance and low allergic potential. In a clinical investigation, Businco et al. (2000) indicated that horse milk was tolerated by $96 \%$ of tested children with cow milk allergies. However, it was tested orally only 2 times. Research has also been conducted with volunteers drinking horse milk over a long period (Foekel et al., 2009); however, in this case, horse milk was studied for multifactorial atopic dermatitis, not strictly a cow milk allergy.

In this study, we demonstrated the effect of horse milk administered constantly over $23 \mathrm{~d}$ in a mouse model of cow milk hypersensitivity. Despite our previous research on horse milk, key questions remain unanswered, such as how horse milk influences gut immunity, in particular the production of $\mathrm{T}$ cells with immunosuppressive activity $\left(\mathbf{T}_{\text {reg }}\right)$ that contribute to intestinal tolerance. In recent years, it has been shown that the gut microbiota play an important role in gut immunity development and contribute to the health of the host with additional metabolic capacities that can have positive effects in increasing the threshold of intestinal tolerance. Experimental models have demonstrated that known beneficial components of the gut microbiota, Bifidobacterium spp. and Lactobacillus spp., significantly contribute to the regulation of inflammatory processes that can occur at the intestinal level (D'Arienzo et al., 2011; Laparra et al., 2012). However, their role in sensitized animal models with cow milk proteins has not been studied until now.

The objective of this study was to evaluate the effects of horse-milk feeding on the markers of gut health (parameters of innate immunity and microbiota composition), as well as potential changes in adaptive immune cell populations in the peripheral blood of mice sensitized against cow milk proteins.

\section{MATERIALS AND METHODS}

\section{Samples}

Horse milk was collected from 12 Warmblood mares of the Wielkopolski breed (Genactiv, Poznań, Poland). After the horses were milked, aliquots of fresh milk were used in microbial analysis, and the remaining aliquots were immediately chilled to $4^{\circ} \mathrm{C}$ and kept frozen at $-20^{\circ} \mathrm{C}$.

\section{Chemical and Microbiological Analysis of Horse Milk}

The chemical composition of the horse milk was analyzed using a MilkoScan FT2 Infrared Milk Analyzer (Foss, Hillerød, Denmark). Plate count agar (105463, Merck, Darmstadt, Germany) was used to assess the total count of viable bacteria (aerobically; $30^{\circ} \mathrm{C} / 72 \mathrm{~h}$ ). Selective media were used to count bacterial cells from the main microbial groups. MacConkey agar (212123, Merck) was used to assess the total number of $E n$ terobacteriaceae (aerobically; $37^{\circ} \mathrm{C} / 24 \mathrm{~h}$ ). Kanamycin esculin azide agar (105222, Merck) was used to assess the total number of enterococci (aerobically; $37^{\circ} \mathrm{C} / 24$ h). De Man, Rogosa and Sharpe agar (PS 60; BioCorp, Warsaw, Poland) was used to assess the total number of mesophilic lactic acid bacteria (aerobically; $30^{\circ} \mathrm{C} / 72 \mathrm{~h}$ ). Dichloran Rose-Bengal Chloramphenicol agar (100466, Merck) was used to assess the total number of mold and yeast cells (aerobically; $25^{\circ} \mathrm{C} / 72 \mathrm{~h}$ ). We pipetted 1 $\mathrm{mL}$ of milk onto Petri dishes in duplicate. Plate count was assessed according to the equation $\mathrm{L}=\Sigma \mathrm{C} /(\mathrm{n} 1+$ $0.1 \mathrm{n} 2) \mathrm{d}$, where $\Sigma \mathrm{C}$ was the sum of colonies counted on all the plates retained; n1 was the number of dishes retained in the first dilution; $\mathrm{n} 2$ was the number of dishes retained in the second dilution; and d was the dilution factor corresponding to the first dilution. In dishes that contained 30 to 300 colonies, the actual number of a dilution on both plates was given. If plates from the lowest dilutions contained fewer than 30 colonies, the actual number was recorded and expressed as colonyforming units per milliliter.

\section{Animals and Experimental Design}

After acclimatizing for $2 \mathrm{wk}$, female BALB/c mice (n $=32$ ) at 6 wk of age, weighing 18 to $22 \mathrm{~g}$, were randomly distributed into 4 groups ( $\mathrm{n}=8 /$ group). Animals were housed in cages. Water and a diet free of dairy protein were provided ad libitum (25\% yellow corn, $13 \%$ red sorghum, $13 \%$ white beans, $9 \%$ green peas, $8 \%$ field peas, $6 \%$ yellow millet, $5 \%$ sorghum white, $4 \%$ husked barley, $3 \%$ canola, $2 \%$ oats without husks, $2 \%$ black sunflower, $2 \%$ striped sunflower, $2 \%$ buckwheat, $2 \%$ kardi, $1 \%$ vitamin mix AIN-93, 3\% mineral mix AIN-93). According to the standard AIN93G rodent diet, the animals received $19.4 \%$ protein, $7.0 \%$ total fat, and $56.8 \%$ carbohydrate. This formulation satisfied the nutritional requirements for growth in mice. We made some modifications to the original formulation to suit our requirements that the diet be free of dairy protein. In the present study, all groups received $16.89 \%$ protein, $6.52 \%$ fat, and $59.13 \%$ carbohydrates (including dietary fiber and sugars). Milk proteins were also avoided in the diets of mice mothers, during suckling of offspring 
until the end of the experiment. Two groups of mice (C/S, sensitized control; HM/S, sensitized and fed horse milk) were immunized via intraperitoneal injections of $50 \mu \mathrm{L}$ of a mixture of $\beta-\mathrm{LG}$ and $\alpha-\mathrm{CN}(100 \mu \mathrm{g} /$ $\mathrm{mL})$ with aluminum adjuvant (1:1 vol/vol; aluminum hydroxide gel; Sigma-Aldrich, Munich, Germany) on d 0,7 , and 14. The cow milk proteins selected were the most allergenic and the most abundant (Natale et al., 2004). We used sensitization by injection with the adjuvant in this study because it has been increasingly applied in mouse models for oral food allergy studies, and mice have a relatively long-lasting immune response (Thang et al., 2013). The other 2 groups (C/NS, control and not sensitized with allergens; HM/NS, fed horse milk and not sensitized with allergens) were administered intraperitoneal PBS. The $\mathrm{C} / \mathrm{NS}$ and $\mathrm{C} / \mathrm{S}$ groups received intragastric PBS; the $\mathrm{HM} / \mathrm{S}$ and HM/NS groups were fed raw horse milk directly to the stomach $(200 \mu \mathrm{L} / \mathrm{d}$ per animal for $23 \mathrm{~d})$ with a blunt stainless steel feeding needle.

Changes in BW were recorded every $2 \mathrm{~d}$. The mice were bled from the tail vein before the first immunization and on $\mathrm{d}$ 0, 7, and 14 after immunization for $\operatorname{IgE}$ analysis. After treatments, the mice were anesthetized (isoflurane, 792632; Sigma-Aldrich) and terminated. Whole-blood samples were preserved in EDTA-treated tubes to prevent coagulation at room temperature for leukocyte analyses. Sections $(1 \mathrm{~cm})$ of the proximal jejunum and liver were immersed in RNAlater reagent (Qiagen, Valencia, CA) at $-80^{\circ} \mathrm{C}$ for gene expression analyses. The study was approved by the Local Ethical Committee in Olsztyn, Poland $(92 / 2012 / \mathrm{N})$.

\section{IgE Determination}

Total serum IgE quantification was performed with ELISA, using a commercial test (555248; OptEIA, BD Biosciences, San Jose, CA).

\section{Lymphocyte Phenotyping}

Aliquots $(50 \mu \mathrm{L})$ of peripheral blood were mixed with the following fluorochrome-conjugated antibodies: fluorescein isothiocyanate (FITC) Rat Anti-Mouse CD3 Molecular Complex (555274; BD Biosciences), PerCP-Cy 5.5 Rat Anti-Mouse CD11b (550993; BD Biosciences), PerCP Rat Anti-Mouse CD8a (55306; BD Biosciences), PE Rat Anti-Mouse Foxp3 (560408; BD Biosciences), Alexa Fluor 700 Rat Anti-Mouse CD4 (557956; BD Biosciences), and APC Rat AntiMouse CD45R/B220 (553092; BD Biosciences). Then, the samples were prepared for flow cytometry analysis with a cell lysis buffer according to the manufacturer's instructions (349202BD; BD Biosciences); samples were analyzed using a flow cytometer (BD LSR Fortessa Cell Analyzer; Erembodegem, Belgium) and FACS Diva Version 6.2 software (BD Biosciences).

\section{Quantitative Reverse-Transcription PCR}

Total cellular RNA was isolated using a GeneMatrix Universal RNA purification kit (E3598; EURx, Gdansk, Poland), dissolved in $40 \mu \mathrm{L}$ of RNase-free water, and stored at $-20^{\circ} \mathrm{C}$. Quantification of RNA was conducted using a NanoDrop ND-1000 photometer (V3.6; Thermo Scientific, Waltham, MA). The PCR was carried out using primers for $T N F-\alpha$ (forward: TTCCTGCACCCTCTGTCTTTC; reverse: CAGTTCTATGGCCCAGACCC), $I L-4$ (forward: GCCTGGGTCAAGCTGACTAC; reverse: ATGTACGATGTCGCCACTCC), MCP-1 (forward: AGCCAACTCTCACTGAAGCC; reverse: GGGTGATATGCTGGGAAGGG), TLR-2 (forward: GACGCTCATGTGAGTGAGTGTA; reverse: AGAGATCACGGACCAAGGGA), and TLR4 (forward: GCTAGCCTGCCTTGTTTCTC; reverse: GGCTTTTTGCCAAGGCT). We used the GADPH gene (forward: CCCTGTTGCTGTAGCCGTAT; reverse: TGGGGATGGGAAACCTGACT) to normalize the results. The total RNA $(0.5 \mu \mathrm{g})$ was converted into first-strand $\mathrm{cDNA}\left(42^{\circ} \mathrm{C}, 50 \mathrm{~min} ; 94^{\circ} \mathrm{C}, 3 \mathrm{~min}\right)$ with AMV reverse transcriptase (Promega, Madison, WI). Gene amplification was performed in 35 cycles, which consisted of the following steps: initial denaturation $\left(94^{\circ} \mathrm{C}, 5 \mathrm{~min}\right)$, denaturation $\left(94^{\circ} \mathrm{C}, 20 \mathrm{~s}\right)$, annealing $\left(53^{\circ} \mathrm{C}, 20 \mathrm{~s}\right)$ and extension $\left(72^{\circ} \mathrm{C}, 40 \mathrm{~s}\right)$. Reaction products were separated via electrophoresis on a $1 \%$ agarose gel with ethidium bromide $(5 \mu \mathrm{g} / \mathrm{mL})$ and quantified using Image Lab version 4.1 (Bio-Rad, Warsaw, Poland).

\section{Bacterial DNA Extraction}

We extracted DNA from colon contents $(0.1 \mathrm{~g})$ using the GeneMATRIX Stool DNA Purification Kit according to the manufacturer's instructions (E3575, EURx; Jurgoński et al., 2015). We isolated DNA using the bead-beating method and a Gyrator UNIPREP 3D vortex (UniEquip, Planegg, Germany). The extracted DNA was stored at $-20^{\circ} \mathrm{C}$.

\section{Real-Time PCR Quantification of Intestinal Microbiota}

Construction of a Standard Curve. To construct a standard curve for the quantification of particular microbiota populations, we used strains representing 
the Bacteroides-Prevotella-Porphyromonas group, the Clostridium leptum group (Clostridium group IV), Bifidobacterium, Enterococcus, and Lactobacillus as the main groups of intestinal microbiota. We applied the approach described by Vahjen et al. (2007), with modifications. Strains were used from the Culture Collection at the Institute of Animal Reproduction and Food Research (Polish Academy of Sciences, Olsztyn, Poland), and from the German Microorganism and Cell-Culture Collection (Leibniz-Institut DSMZ-Deutsche Sammlung von Mikroorganismen und Zellkulturen $\mathrm{GmbH}$, Braunschweig, Germany). The bacterial cultures were cultivated separately in appropriate conditions (details available upon request). The cell number of each culture was determined using 4',6-diamidino-phenylindole (Świątecka et al., 2013). Two milliliters of each culture was centrifuged $(5 \mathrm{~min}, 10,000 \times g)$, washed with sterile PBS ( $\mathrm{pH}$ 7.4), and centrifuged again. Cell pellets were combined and mixed with $0.1 \mathrm{~g}$ of autoclaved cecal contents (autoclaved twice; $121^{\circ} \mathrm{C}, 15 \mathrm{~min}$ ), and bacterial DNA was isolated using the same method as for the cecal samples. Isolated DNA was serially diluted 10-fold, and dilutions from $10^{-1}$ to $10^{-7}$ were used to construct the standard curves. We carried out real-time PCR amplifications with genus- and groupspecific primers to obtain the curve for each of the tested bacterial populations. The starting bacterial cell number in the standard was $3.27 \times 10^{9}$ for the total bacteria number, $3.18 \times 10^{8}$ for Bacteroides, $3.99 \times$ $10^{7}$ for the Clostridium leptum group, $1.44 \times 10^{9}$ for Bifidobacterium, $1 \times 10^{9}$ for Enterococcus, and $5.35 \times$ $10^{8}$ for Lactobacillus.

Quantification of Intestinal Bacteria. For each real-time PCR experiment, a standard curve was prepared, and the standard samples and test samples were run in duplicate. Reactions were carried out using an iQ5 real-time PCR system (Bio-Rad) in a total volume of $25 \mu \mathrm{L}$, consisting of $12.5 \mu \mathrm{L}$ of SYBR Green JumpStart Taq ReadyMix (Sigma, Poznan, Poland), 200 $\mu M$ of each primer, $1 \mu \mathrm{L}$ of DNA diluted 10-fold, and PCR-grade water (Sigma). The primer sequences and annealing temperatures are listed in Supplementary Table S1 (http://dx.doi.org/10.3168/jds.2016-11499). The temperature program included 1 cycle of $95^{\circ} \mathrm{C}$ for $3 \mathrm{~min}$ and 35 cycles of $95^{\circ} \mathrm{C}$ for $20 \mathrm{~s}$, the temperature of primer annealing (Table S1) for $30 \mathrm{~s}$, and $72^{\circ} \mathrm{C}$ for $30 \mathrm{~s}$ with signal acquisition. After completion of the amplifications, we prepared a melting curve to confirm the specificity of the PCR products. We analyzed the recorded data using iQ5 Optical System Software (version 2.0; Bio-Rad), and normalized the obtained values according to the dilution and weight of the sample. The results are expressed as $\log _{10}$ of the cell number per gram of sample wet weight.

\section{Statistical Analysis}

All analyses were conducted in triplicate. Statistical analysis was performed using Statistica software, version 10.0 (StatSoft Corp., Kraków, Poland). Data were analyzed using the Kruskal-Wallis one-way ANOVA, followed by Dunn's post hoc test. If ANOVA assumptions were violated, we used the Wilcoxon matched-pairs test or $t$-test. Statistical significance was established at $P<$ $0.10, P<0.05, P<0.01$, and $P<0.001$.

\section{RESULTS AND DISCUSSION}

\section{Chemical and Microbiological Analysis of Horse Milk}

The major chemical components and physical parameters of the horse milk are shown in Table 1 . The lactose concentration was particularly high compared with that of several other animal species (e.g., cattle, buffalo, sheep, goat, camel, llama, alpaca, yak, and reindeer), as previously determined by Barłowska et al. (2011). Notably, a beneficial role has been suggested for lactose. Cederlund et al. (2013) attributed an immune-modulatory role to lactose in promoting the upregulation of gastrointestinal antimicrobial peptide LL-37, which serves to protect the neonatal gut against pathogens and exerts a regulatory effect on the microbiota composition of the infant. Paasela et al. (2014) proposed that breast milk lactose could have beneficial effects on immunity during infancy by indirectly enhancing the IFN- $\gamma$ and IL-17 responses of effector $\mathrm{T}$ cells, although they pointed out that in individuals susceptible to chronic inflammatory diseases, dietary lactose could induce harmful inflammatory responses by disrupting $\mathrm{T}_{\text {reg }}$ cells. In a study on galectin-9/TIM-3 interactions, the authors showed that memory $\mathrm{CD} 8^{+}$ T-cell populations can be expanded using $\alpha$-lactose, a possible way to enhance antimicrobial immunity (Sehrawat et al., 2010). Data concerning the fat and protein content of horse milk revealed a more similar casein:whey protein ratio to human milk, which could have important consequences for intestinal tolerance processes (Lara-Villoslada et al., 2005). An additional advantageous immuno-nutritional feature could be the lower proportion of immunogenic peptides produced from horse milk after simulated gastrointestinal digestion and the lower uptake of those peptides by intestinal cells compared with those of cow milk (Picariello et al., 2013; Fotschki et al., 2015b).

According to the scant scientific literature, bacterial total plate counts for horse milk are lower than those for cow milk (Doreau and Martin-Rosset, 2002). This could be explained by the higher lysozyme and lactoferrin content and the iron-binding capacity of lactoferrin 
IMMUNE-MODULATING PROPERTIES OF HORSE MILK

Table 1. Chemical composition and physical parameters of horse milk

\begin{tabular}{lcl}
\hline Parameter & Mean & SD \\
\hline Lactose (\%) & 7.28 & 0.02 \\
Fat (\%) & 0.64 & 0.03 \\
Proteins (\%) & 1.55 & 0.01 \\
Caseins (\%) & 1.34 & 0.05 \\
Citric acid (\%) & 0.1 & 0.01 \\
Fat-free DM (g/L) & 96.11 & 0.25 \\
DM (g/L) & 97.55 & 0.26 \\
Density (g/L) & 1.035 & 0.08 \\
Freezing point $\left(-{ }^{\circ} \mathrm{C}\right)$ & 0.516 & 1.0 \\
\hline
\end{tabular}

in horse milk (Claeys et al., 2014). The cell numbers of the main microbiological groups we assessed in the horse milk are shown in Table 2 . The total viable counts determined were similar to previously reported values (Danków et al., 2006). The majority of detected bacteria from horse milk originated from mesophilic lactic acid bacteria strains. Enterobacteria and enterococci were detectable at low counts, and yeast cells had the lowest numbers; molds were not detectable. Microbiological analysis indicated that proper hygiene was practiced during milking. The standard limit for microbial counts in raw milk has been set by the European Community at $1 \times 10^{5} \mathrm{cfu} / \mathrm{mL}$ to $5 \times 10^{5} \mathrm{cfu} / \mathrm{mL}$ (Tasnim and Islam, 2015).

\section{Serum IgE Levels}

Several attempts have been made to develop animal models that mimic the major clinical features of food allergy, such as IgE-mediated food hypersensitivity in mice sensitized to cow milk protein (Sari et al., 2010; Stojadinovic et al., 2014). We selected BALB/c mice because they are frequently used for a variety of immunological studies and are high IgE responders (Dearman and Kimber, 2007). In the present study, the administration regimen and doses of cow milk proteins used during the immunization process were effective in significantly increasing total serum IgE levels, demonstrating an adequate immune response against major cow milk allergens ( $\alpha-\mathrm{CN}$ and $\beta-\mathrm{LG}$ ). After sensitization, the levels of IgE increased by more than 8-fold in relation to the values quantified before immunization (Figure 1A).

Administration of horse milk to mice that were not immunized with allergens caused an increase in total $\mathrm{IgE}$ levels. The observed effect could be a physiological response of the immune system of BALB/c mice to heterogeneous sources of proteins in the diet. We observed an increase of total IgE in healthy mice in other studies with cow milk proteins (unpublished data). Notably, the mice fed horse milk had total IgE levels only 2.2fold higher than the sensitized controls (Figure 1B).
Table 2. Cell numbers (cfu/mL) of the bacterial groups in horse milk

\begin{tabular}{llc}
\hline Parameter & Mean & SEM \\
\hline Total viable count & $1.01 \times 10^{5}$ & $9.51 \times 10^{4}$ \\
Mesophilic lactic acid bacteria & $2.28 \times 10^{3}$ & $9.00 \times 10^{2}$ \\
Molds & $\mathrm{ND}^{1}$ & - \\
Yeasts & 3.21 & 1.80 \\
Enterobacteriaceae & $1.88 \times 10^{1}$ & $1.78 \times 10^{1}$ \\
Enterococci & $1.07 \times 10^{1}$ & $6.70 \times 10^{0}$ \\
\hline
\end{tabular}

${ }^{1} \mathrm{ND}=$ not detectable. The limit of detection was $1 \mathrm{cfu} / \mathrm{mL}$.

This result may have been caused by low homology between the main cow and horse milk proteins $(62.4 \%$ average for $\alpha_{\mathrm{S} 1}-\mathrm{CN}, \beta-\mathrm{CN}, \kappa-\mathrm{CN}, \alpha-\mathrm{LA}, \beta-\mathrm{LG}$, serum albumin), which is $43.3 \%$ for $\alpha_{\mathrm{S}^{-}} \mathrm{CN}$ and $59.4 \%$ for $\beta$-LG (Karabus and du Toit, 2012).

\section{Leukocyte Count and Lymphocyte Phenotyping}

We used the cell surface marker CD45R/B220 to identify the general leukocyte population, and conducted further T-cell phenotyping analyses in this population. Transcription factor Foxp3 is critical for the development and function of $\mathrm{T}_{\mathrm{reg}}$ (Baron et al., 2007). The changes in peripheral leukocyte populations in nonsensitized and sensitized controls and in mice fed horse milk are shown in Figure 2. Sensitization with cow milk proteins caused a significant decrease in the $\mathrm{CD} 4^{+}$Foxp $3^{+}$lymphocyte population in the mice in the control group. We also observed a decreased CD8 ${ }^{+}$ population in the peripheral blood $(P<0.05)$. Stock et al. (2004) showed that depletion of $\mathrm{CD}^{+} \mathrm{T}$ cells before immunization led to increased T helper 2 (Th2) responses and increased allergic airway disease, highlighting protective effect of $\mathrm{CD} 8^{+} \mathrm{T}$ cells against the induction of adverse immune responses.

Horse-milk administration to sensitized and nonsensitized mice caused a significant increase in $\mathrm{CD} 4^{+} \mathrm{Foxp} 3^{+}$, which was reflected in a decrease in the $\mathrm{CD} 4^{+} \mathrm{Foxp} 3^{-}$ lymphocyte population in peripheral blood. Leukocyte counts and phenotyping analyzes of T-cell subsets in peripheral blood indicated that the sensitization of the mice with cow milk allergens ( $\beta-\mathrm{LG}$ and $\alpha \mathrm{CN}$ ) was relatively effective in stimulating T-cell-mediated response(s) associated with allergic processes. Thus, the effect in allergic patients was partially mimicked. The most remarkable alterations have been noted in $\mathrm{T}_{\text {reg }}$ cells $\left[\mathrm{CD} 4^{+}\right.$Foxp $\left.3^{+}\right]$, which have been shown to exert suppressive effects on innate immune reactions (Hou et al., 2015). Evidence also shows that Foxp3 ${ }^{+}$ induced $\mathrm{T}_{\mathrm{reg}}$ are required for oral tolerance (Hadis et al., 2011) and act locally in the gut, preventing chronic inflammation from excessive immune reactivity against food proteins. In one study, increase of $\mathrm{T}_{\text {reg }}$ cells results 

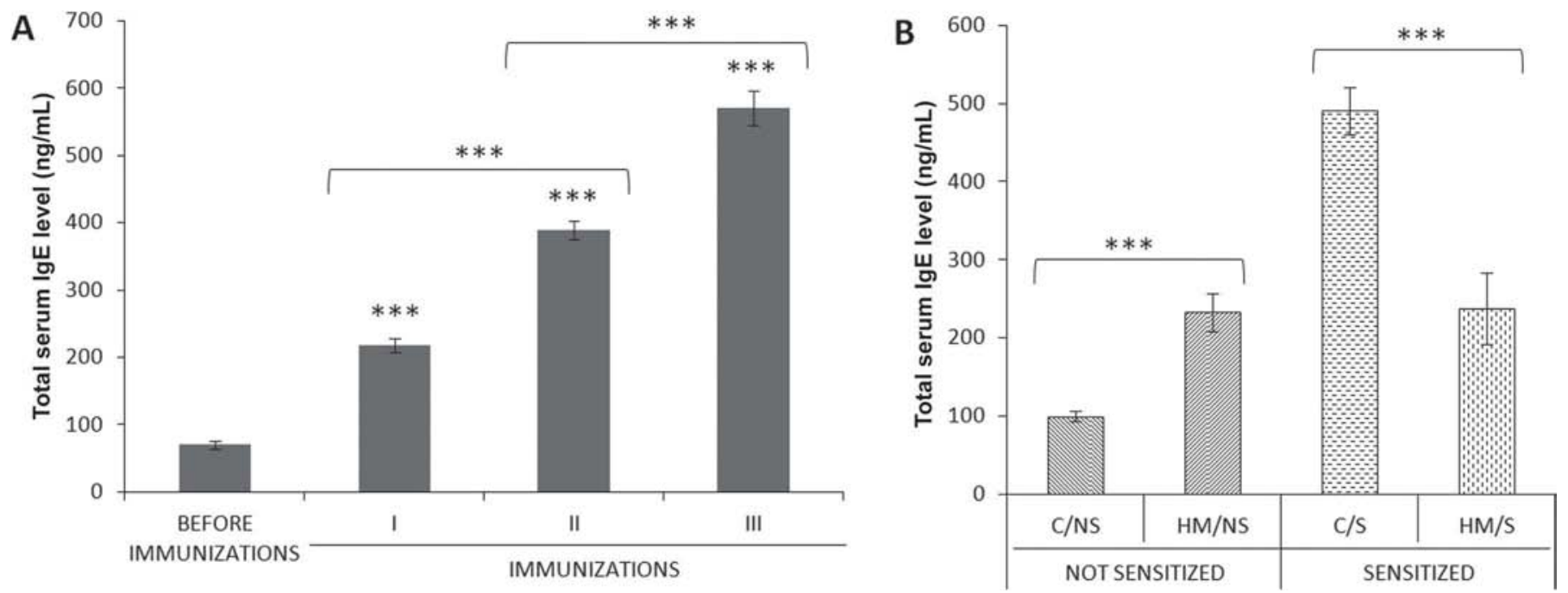

Figure 1. Changes in the total serum IgE concentration $(\mathrm{ng} / \mathrm{mL})$ in BALB/c mice during the experiment. (Panel A) Changes in IgE levels after mouse immunizations intraperitoneal injections on d 0 (I), 7 (II), and 14 (III) with $50 \mu \mathrm{L}$ of a mixture of $50 \mu \mathrm{g} / \mathrm{mL}$ cow milk $\beta$-lactoglobulin and $50 \mu \mathrm{g} / \mathrm{mL}$ cow milk $\alpha$-casein with $50 \mu \mathrm{g} / \mathrm{mL}$ aluminum adjuvant (1:1 vol/vol)]. (Panel B) Comparison of total serum IgE levels of sensitized and nonsensitized animals at the end of the experiment. The graph shows the values from the groups that received intragastric horse milk (HM; $200 \mu \mathrm{L} / \mathrm{d}$ per animal) or PBS (C) and received intraperitoneal injections of allergens + aluminum adjuvant (C/S, HM/S) or PBS (C/NS, $\mathrm{HM} / \mathrm{NS}$ ). Results are expressed as mean $\pm \mathrm{SEM} ; * * * P<0.001$ (differences between immunized mice and before-immunization control and among immunizations).

in reduced $\mathrm{IgE}$ production in BALB/c mice (Schulze et al., 2016). The authors concluded that expansion of $\mathrm{CD}^{+}{ }^{+}$Foxp $^{+}{ }^{+} \mathrm{T}_{\text {reg }}$ cells has a therapeutic effect by limiting allergic airway inflammation. The low reactivity of horse milk is supported by the decreased IgE levels quantified in the mice sensitized with allergens (Figure 1 ). The present study demonstrated that sensitization before horse milk administration was necessary to in-

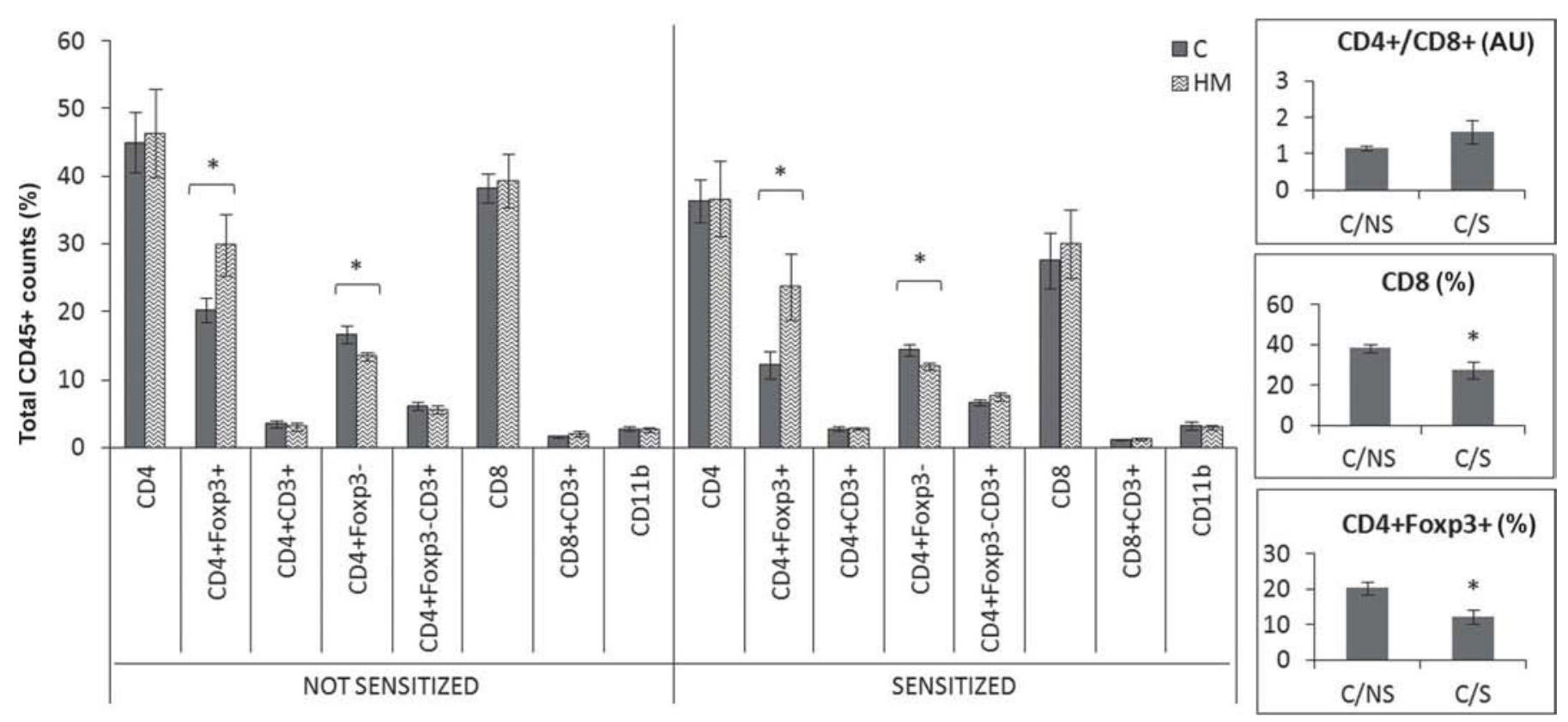

Figure 2. Analysis of immunocompetent cell populations. The graph shows the values from the groups that received intragastric horse milk $(\mathrm{HM} ; 200 \mu \mathrm{L} / \mathrm{d}$ per animal) or PBS (C) and received intraperitoneal injections of allergens + aluminum adjuvant $(\mathrm{C} / \mathrm{S}$, HM/S; sensitized) or PBS (C/NS, HM/NS; nonsensitized). Cell subpopulations have been identified as a percentage of the parent population. Results are expressed as mean \pm SEM. ${ }^{*} P<0.05$. AU $=$ arbitrary unit. 


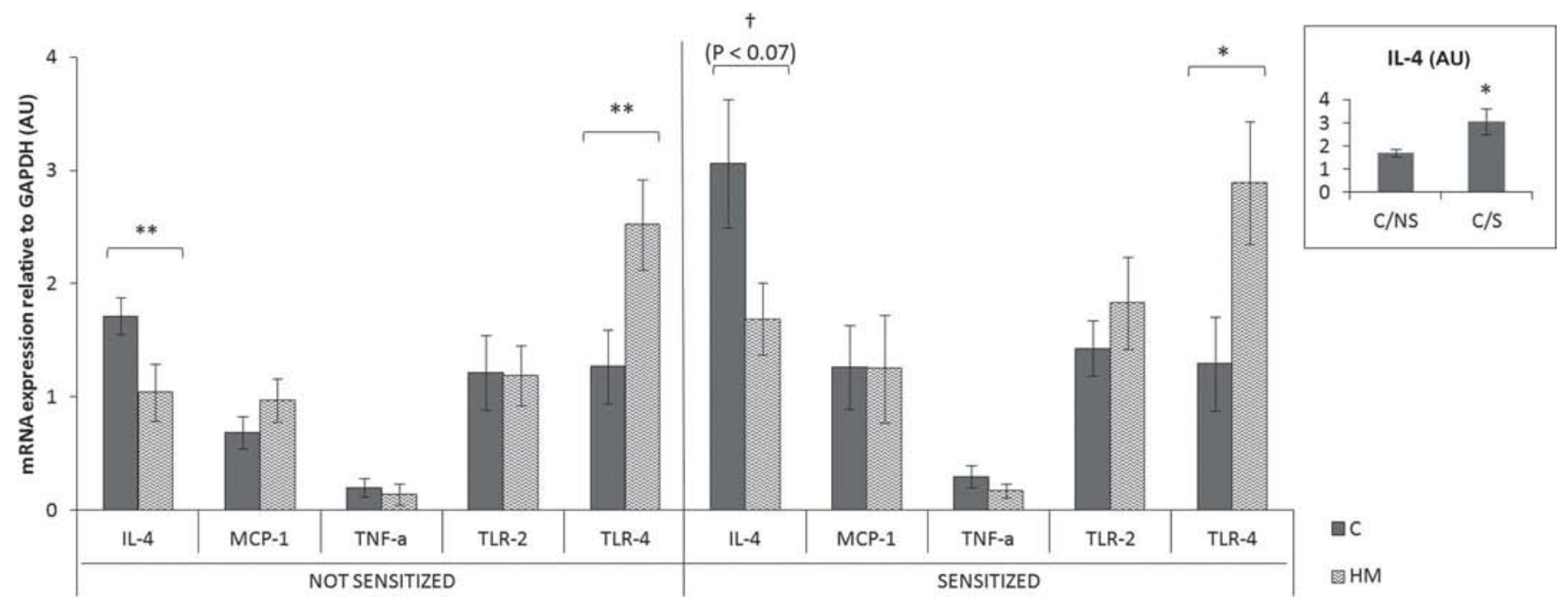

Figure 3. Quantitative reverse-transcription PCR analysis of the mRNA expression of immune markers in intestinal tissue samples. The graph shows the values from the groups that received intragastric horse milk (HM; $200 \mu \mathrm{L} / \mathrm{d}$ per animal) or PBS (C) and received intraperitoneal injections of allergens + aluminum adjuvant $(\mathrm{C} / \mathrm{S}, \mathrm{HM} / \mathrm{S}$; sensitized) or PBS (C/NS, HM/NS; nonsensitized). Results are expressed as mean \pm SEM; $\dagger P<0.10,{ }^{*} P<0.05,{ }^{*} * P<0.01$. AU $=$ arbitrary unit.

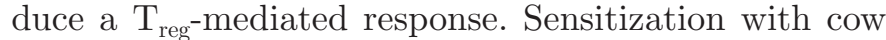
milk proteins probably caused the extravasation of this cell population to other physiological compartments, where their activation could take place. A food allergy is considered a skewed Th2 response of the body, especially in the intestine.

\section{mRNA Expression of Innate Markers in the Intestine}

The intestine is constantly exposed to dietary antigens, which have to be tolerated by the immune system (innate and adaptive) to maintain homeostasis. In this study, animals (sensitized or not) that were fed horse milk showed a reduced expression of mRNA $I L-4$ (Figure 3). The mRNA expression of $I L$ - 4 increased after immunization but was reduced to the level of $\mathrm{C} / \mathrm{NS}$ mice with horse-milk treatment. Because of its role as a Th2-like cytokine, IL-4 has been suggested as a potential target for allergy treatment (Schmidt-Weber, 2012). It has been shown that IL-4 alone can act as a proinflammatory cytokine in the gut of mice (Van Kampen et al., 2005). Burton et al. (2013) demonstrated that IL4-signaling is a key determinant of mast cell expansion and increased susceptibility to anaphylaxis in a murine model of food allergy. Intestinal inflammation due to allergenic foods is accompanied by Th2 cells and cellular responses that are largely dependent on $\operatorname{IgE}$ (Forbes et al., 2008). This is in accordance with the decreased $\mathrm{IgE}$ levels quantified in animals fed horse milk (Figure 1B). Similarly, the expression of TNF- $\alpha$, a potent proinflammatory cytokine impairing intestinal perme- ability (Ma et al., 2004), showed a decreasing trend in nonsensitized mice fed horse milk. Feeding horse milk to nonsensitized animals did not significantly affect the expression of $M C P-1$ at the intestinal level. One of the key chemokines that regulate the migration and infiltration of monocytes/macrophages, MCP-1 plays an important role in the induction of the inflammatory immune response. Notably, the lack of response in the expression of other innate markers in sensitized animals could be explained, at least in part, by the development of a tolerance during the treatment period.

At the intestinal level, feeding horse milk to nonsensitized mice significantly increased the expression of TLR-4, but not TLR-2 (Figure 3). These results show that the intestine supplies not only nutrients but also immune signals that stem from intestinal cells, revealing the importance of this organ in the development of immunonutritional processes. Some experimental studies have indicated the protective role of toll-like receptors (TLR) in the development of allergic diseases (Lombardi et al., 2008; Dębińska and Boznański, 2014) and in contributing to the maintenance of intestinal homeostasis (Taniguchi et al., 2009). Activating signals through TLR4 promotes innate immune cell migration (Liu et al., 2013).

Numerous studies have provided evidence that TLR4 is the signaling receptor for LPS (Lu et al., 2008). The stimulation of TLR 4 by LPS induces the release of critical proinflammatory cytokines necessary to activate potent immune responses. However, according to Vordenbäumen et al. (2016) and Erridge (2010), not 
only LPS, but also milk components and host-derived molecules may stimulate TLR4-dependent signaling. Vordenbäumen et al. (2016) showed that human $\alpha_{S^{-}}$ CN (CSN1S1) induced expression of proinflammatory cytokines via TLR4 (this process was not dependent upon LPS) and phosphorylation of CSN1S1 inhibited binding to TLR4 and proinflammatory properties. The authors claimed that CSN1S1 might thus be regarded as a bioactive food component. Erridge (2010) proposed more than 20 endogenous TLR ligands, which have tended to fall into the categories of released intracellular proteins, extracellular matrix components, oxidatively modified lipids, and other soluble mediators.

\section{Quantification of Colonic Microbiota}

The quantification of the microbial composition of the different treatment groups revealed that the dietary consumption of horse milk had a positive effect, resulting in higher proportions of Bifidobacterium spp. in sensitized and nonsensitized mice (Figure 4). The shift in gut microbiota composition induced by horse milk can be considered to benefit the host via a healthier intestinal environment.

The observed increase in Bifidobacterium cell numbers is in agreement with previous findings, where 23 patients with atopic dermatitis consumed $250 \mathrm{~mL}$ of horse milk or placebo for 16 weeks, and fecal bifidobacteria increased with the horse-milk diet (from 4.6 to $11.9 \%$; Foekel et al., 2009). This could be of particular importance, because recent data have shown a direct link between gut microbiota and the regulation of host immunity, revealing promising strategies for the treatment of cow milk allergy based on modulating the composition or functionality of the gut microbiome, or both (Berni Canani et al., 2015). Notably, reduced intestinal colonization with the genera of Bifidobacterium and Lactobacillus in allergic children has been reported (Kalliomäki and Isolauri, 2003). The effect on Bifidobacterium induced by horse milk could be attributed to its lactose content, as it has been shown in infants with cow milk allergy that the total fecal counts of Lactobacillus/Bifidobacterium increased and those of Bacteroides/Clostridia species decreased after the consumption of lactose for 2 mo (Francavilla et al., 2012). In addition, previous studies have demonstrated that a defined strain of Bifidobacterium longum (CECT 7347) induced higher counts of $\mathrm{CD} 8^{+} \mathrm{T}$ cells in animals sensitized to interferon- $\gamma$ animals (Laparra et al., 2012). Cytokine induction by bifidobacteria is strain-dependent and related to different immunologic status (He et al., 2002). Thus, the role of bifidobacteria in allergic diseases remains to be fully determined.

\section{CONCLUSIONS}

This study reports on the immune-modulating effects of feeding horse milk to control and cow-milk-

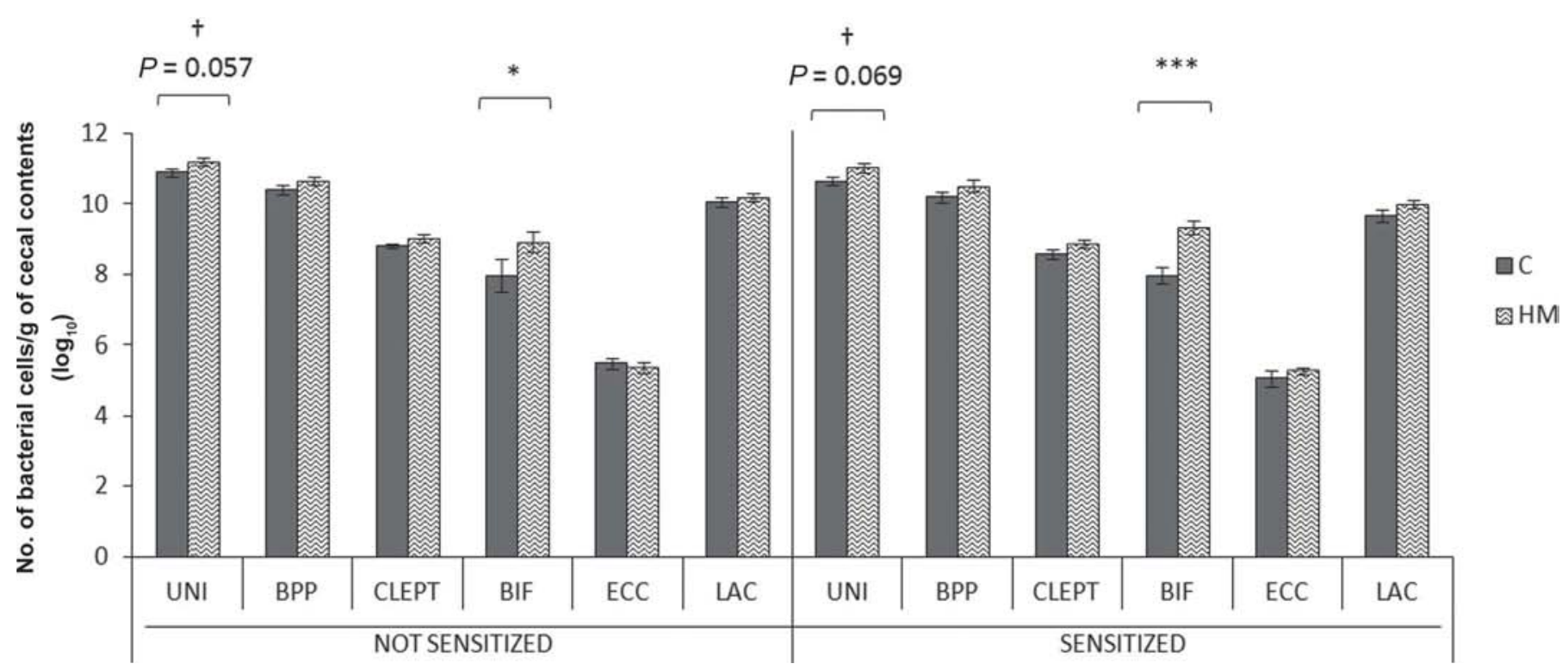

Figure 4. Real-time PCR analysis. Results are $\log _{10}$ of bacterial cells per gram wet weight of cecal content of animals that received intragastric horse milk (HM; $200 \mu \mathrm{L} / \mathrm{d}$ per animal) or PBS (C) and received intraperitoneal injections of allergens + aluminum adjuvant (C/S, HM/S; sensitized) and PBS (C/NS, HM/NS; nonsensitized). Results are expressed as mean $\pm \mathrm{SEM} ; P<0.10, * P<0.05, * * * P<0.001$. BIF $=$ Bifidobacterium group; BPP = Bacteroides-Prevotella-Porphyromonas group; CLEPT = Clostridium leptum group; ECC $=$ Enterococcus group; $\mathrm{LAC}=$ Lactobacillus group; $\mathrm{UNI}=$ total bacteria. 
sensitized mice. We observed beneficial alterations in the composition of gut microbiota, favoring the growth of Bifidobacterium spp. in the intestinal milieu after horse-milk treatment. The increase was quantified in sensitized mice, and also in mice fed horse milk that were not sensitized with allergens. The low protein concentration in horse milk is of particular importance, because proteins represent the major contributors to allergic processes, especially in neonates. This study demonstrated the positive effects of feeding horse milk on decreasing IgE levels in immunized animals and in the associated increased counts of $\mathrm{T}_{\text {reg }}$ cells, which have an immunosuppressive role. The results indicate that horse milk elicits a positive effect on innate response(s), decreasing the expression of $I L-4$ (which has proinflammatory properties), and increasing that of $T L R-4$, independent of the state of the animal. We propose that horse milk does not fully abolish allergic sensitization, but it may reduce its incidence, a finding that merits further investigation in clinical trials. Future studies should focus on testing horse-milk processing, such as fermentation and destroying most allergenic epitopes to continue research under clinical conditions.

\section{ACKNOWLEDGMENTS}

We are grateful to the microbiological laboratory for their excellent technical support. We thank the Genactiv Company for the horse milk. This study was supported by the European Union within the European social fund, the National Science Center (Poland, No. UMO-2015/17/N/NZ9/03666) and the statutory fund of the Department of Immunology and Food Microbiology, Institute of Animal Reproduction and Food Research, Polish Academy of Sciences, Olsztyn.

\section{REFERENCES}

Barłowska, J., M. Szwajkowska, Z. Litwińczuk, and J. Król. 2011. Nutritional value and technological suitability of milk from various animal species used to dairy production. Compr. Rev. Food Sci. Food Saf. 10:291-302.

Baron, U., S. Floess, G. Wieczorek, K. Baumann, A. Grützkau, J. Dong, A. Thiel, T. J. Boeld, P. Hoffmann, M. Edinger, I. Türbachova, A. Hamann, S. Olek, and J. Huehn. 2007. DNA demethylation in the human FOXP3 locus discriminates regulatory $\mathrm{T}$ cells from activated $\mathrm{FOXP}^{+}{ }^{+}$conventional $\mathrm{T}$ cells. Eur. J. Immunol. 37:2378-2389.

Burton, O. T., A. R. Darling, J. S. Zhou, M. Noval-Rivas, T. G. Jones, M. F. Gurish, T. A. Chatila, and H. C. Oettgen. 2013. Direct effects of IL-4 on mast cells drive their intestinal expansion and increase susceptibility to anaphylaxis in a murine model of food allergy. Mucosal Immunol. 6:740-750.

Businco, L., P. G. Giampietro, P. Lucenti, F. Lucaroni, C. Pini, G. Di Felice, P. Iacovacci, C. Curadi, and M. Orlandi. 2000. Allergenicity of mare's milk in children with cow's milk allergy. J. Allergy Clin. Immunol. 105:1031-1034.
Berni Canani, R., J. A. Gilbert, and C. R. Nagler. 2015. The role of the commensal microbiota in the regulation of tolerance to dietary allergens. Curr. Opin. Allergy Clin. Immunol. 15:243-249.

Cederlund, A., Y. Kai-Larsen, G. Printz, H. Yoshio, G. Alvelius, H. Lagercrantz, R. Strömberg, H. Jörnvall, G. H. Gudmundsson, and B. Agerberth. 2013. Lactose in human breast milk an inducer of innate immunity with implications for a role in intestinal homeostasis. PLoS One. 8:e53876.

Claeys, W., C. Verraes, S. Cardoen, J. De Block, K. Dewettinck, A. Huyghebaert, K. Raes, K. Dewettinck, and L. Herman. 2014. An evaluation of the nutritional (and health) benefits of the consumption of raw milk from different species. Food Contr. 42:188-201.

D'Arienzo, R., R. Stefanile, F. Maurano, G. Mazzarella, E. Ricca, R. Troncone, S. Auricchio, and M. Rossi. 2011. Immunomodulatory effects of Lactobacillus casei administration in a mouse model of gliadin-sensitive enteropathy. Scand. J. Immunol. 74:335-341.

Danków, R., J. Wójtowski, J. Pikul, R. Niżnikowski, and D. CaisSokolińska. 2006. Effect of lactation on the hygiene quality and some milk physicochemical traits of the Wielkopolska mares. Arch. Tierz. Dummerstorf. 49:201-206.

Dearman, R. J., and I. Kimber. 2007. A mouse model for food allergy using intraperitoneal sensitization. Methods 41:91-98.

Dębińska, A., and A. Boznański. 2014. The role of Toll-like receptors in the pathogenesis of allergic diseases-where is the truth? Postepy Hig. Med. Dosw. (Online). 68:230-237. [In Polish]

Doreau, M., and W. Martin-Rosset. 2002. Dairy animals: Horse. Pages 358-365 in Encyclopedia of Dairy Sciences. H. Roginsky, J. W. Fuquay, P. F. Fox, ed. Academic Press, London, UK.

El-Agamy, E. I. 2007. The challenge of cow milk protein allergy. Small Rumin. Res. 68:64-72.

Erridge, C. 2010. Endogenous ligands of TLR2 and TLR4: Agonists or assistants? J. Leukoc. Biol. 87:989-999.

Fiocchi, A., J. Brozek, H. Schünemann, S. L. Bahna, A. von Berg, K. Beyer, M. Bozzola, J. Bradsher, E. Compalati, M. Ebisawa, M. A. Guzmán, H. Li, R. G. Heine, P. Keith, G. Lack, M. Landi, A. Martelli, F. Rancé, H. Sampson, A. Stein, L. Terracciano, S. Vieths, and World Allergy Organization (WAO) Special Committee on Food Allergy. 2010. World Allergy Organization (WAO) diagnosis and rationale for action against Cow's milk allergy (DRACMA) guidelines. Pediatr. Allergy Immunol. 21:1-125.

Foekel, C., R. Schubert, M. Kaatz, I. Schmidt, A. Bauer, U. C. Hipler, H. Vogelsang, K. Rabe, and G. Jahreis. 2009. Dietetic effects of oral intervention with mare's milk on the severity scoring of atopic dermatitis, on fecal microbiota and on immunological parameters in patients with atopic dermatitis. Int. J. Food Sci. Nutr. 60:41-52.

Forbes, E. E., K. Groschwitz, J. P. Abonia, E. B. Brandt, E. Cohen, C. Blanchard, R. Ahrens, L. Seidu, A. McKenzie, R. Strait, F. D. Finkelman, P. S. Foster, K. I. Matthaei, M. E. Rothenberg, and S. P. Hogan. 2008. IL-9- and mast cell-mediated intestinal permeability predisposes to oral antigen hypersensitivity. J. Exp. Med. 205:897-913.

Fotschki, J., A. Szyc, J. M. Laparra, and B. Wróblewska. 2015b. Mare's and cow's milk: Promote similar metabolic effects and expression of innate markers in Caco-2 cells? Food Res. Int. 72:184-190.

Fotschki, J., A. Szyc, and B. Wróblewska. 2015a. Immunoreactivity of lactic acid-treated mare's milk after simulated digestion. J. Dairy Res. 82:78-85.

Francavilla, R., M. Calasso, L. Calace, S. Siragusa, M. Ndagijimana, P. Vernocchi, L. Brunetti, G. Mancino, G. Tedeschi, E. Guerzoni, F. Indrio, L. Laghi, V. L. Miniello, M. Gobbetti, and M. De Angelis. 2012. Effect of lactose on gut microbiota and metabolome of infants with cow's milk allergy. Pediatr. Allergy Immunol. 23:420-427.

Hadis, U., B. Wahl, O. Schulz, M. Hardtke-Wolenski, A. Schippers, N. Wagner, W. Müller, T. Sparwasser, R. Förster, and O. Pabst. 2011. Intestinal tolerance requires gut homing and expansion of FoxP3+ regulatory $\mathrm{T}$ cells in the lamina propria. Immunity. 34:237-246.

He, F., H. Morita, A. C. Ouwehand, M. Hosoda, M. Hiramatsu, J. Kurisaki, E. Isolauri, Y. Benno, and S. Salminen. 2002. Stimulation of the secretion of pro-inflammatory cytokines by Bifidobacterium strains. Microbiol. Immunol. 46:781-785. 
Hou, X., J. Song, J. Su, D. Huang, W. Gao, J. Yan, and J. Shen. 2015. CD4(+)Foxp3(+) Tregs protect against innate immune cellmediated fulminant hepatitis in mice. Mol. Immunol. 63:420-427.

Jurgoński, A., J. Juśkiewicz, B. Fotschki, K. Kołodziejczyk, J. Milala, M. Kosmala, K. Grzelak-Błaszczyk, and L. Markiewicz. 2015. Metabolism of strawberry mono- and dimeric ellagitannins in rats fed a diet containing fructo-oligosaccharides. Eur. J. Nutr. http:// dx.doi.org/http://dx.doi.org/10.1007/s00394-015-1133-5.

Kalliomäki, M., and E. Isolauri. 2003. Role of intestinal flora in the development of allergy. Curr. Opin. Allergy Clin. Immunol. 3:15-20.

Karabus, S. J., and G. du Toit. 2012. IgE-mediated cow's milk protein allergy. Curr. Opin. Allergy Clin. Immunol. 25:4-9.

Laparra, J. M., M. Olivares, O. Gallina, and Y. Sanz. 2012. Bifidobacterium longum CECT 7347 modulates immune responses in a gliadin-induced enteropathy animal model. PLoS One. 7:e30744.

Lara-Villoslada, F., M. Olivares, and J. Xaus. 2005. The balance between caseins and whey proteins in cow's milk determines its allergenicity. J. Dairy Sci. 88:1654-1660.

Liu, Z., Y. Jiang, Y. Li, J. Wang, L. Fan, M. J. Scott, G. Xiao, S. Li, T. R. Billiar, M. A. Wilson, and J. Fan. 2013. TLR4 Signaling augments monocyte chemotaxis by regulating $\mathrm{G}$ protein-coupled receptor kinase 2 translocation. J. Immunol. 191:857-864.

Lombardi, V., L. Van Overtvelt, S. Horiot, H. Moussu, H. Chabre, A. Louise, A. M. Balazuc, L. Mascarell, and P. Moingeon. 2008. Toll-like receptor 2 agonist Pam3CSK4 enhances the induction of antigen-specific tolerance via the sublingual route. Clin. Exp. Allergy 38:1819-1829.

Lu, Y. C., W. C. Yeh, and P. S. Ohashi. 2008. LPS/TLR4 signal transduction pathway. Cytokine. 42:145-151.

Ma, T. Y., G. K. Iwamoto, N. T. Hoa, V. Akotia, A. Pedram, M. A. Boivin, and H. M. Said. 2004. TNF-alpha-induced increase in intestinal epithelial tight junction permeability requires NFkappa B activation. Am. J. Physiol. Gastrointest. Liver Physiol. 286:G367-376.

Natale, M., C. Bisson, G. Monti, A. Peltran, L. P. Garoffo, S. Valentini, C. Fabris, E. Bertino, A. Coscia, and A. Conti. 2004. Cow's milk allergens identification by two-dimensional immunoblotting and mass spectrometry. Mol. Nutr. Food Res. 48:363-369.

Nikkhah, A. 2012. Equidae milk promises substitutes for cow and human breast milk. Turk. J. Vet. Anim. Sci. 36:470-475.

Paasela, M., K. L. Kolho, O. Vaarala, and J. Honkanen. 2014. Lactose inhibits regulatory T-cell-mediated suppression of effector T-cell interferon- $\gamma$ and IL-17 production. Br. J. Nutr. 112:1819-1825.

Picariello, G., G. Iacomino, G. Mamone, P. Ferranti, O. Fierro, C. Gianfrani, A. Di Luccia, and F. Addeo. 2013. Transport across Caco-2 monolayers of peptides arising from in vitro digestion of bovine milk proteins. Food Chem. 139:203-212.

Restani, P., B. Beretta, A. Fiocchi, C. Ballabio, and C. L. Galli. 2002 Cross-reactivity between mammalian proteins. Ann. Allergy Asthma Immunol. 89:11-15.
Sari, A., E. Dinc, B. C. Yilmaz, U. Adiguzel, S. Oztuna, and B. Tasdelen. 2010. Inducing ocular allergy with beta-lactoglobulin: a new experimental model. Ophthalmic Res. 44:119-124.

Schmidt-Weber, C. B. 2012. Anti-IL-4 as a new strategy in allergy. Chem. Immunol. Allergy 96:120-125.

Schulze, B., D. Piehler, M. Eschke, L. Heyen, M. Protschka, G. Köhler, and G. Alber. 2016. Therapeutic expansion of CD4+FoxP3+ regulatory $\mathrm{T}$ cells limits allergic airway inflammation during pulmonary fungal infection. Pathog. Dis. 74.ftw020.

Sehrawat, S., P. B. Reddy, N. Rajasagi, A. Suryawanshi, M. Hirashima, and B. T. Rouse. 2010. Galectin-9/TIM-3 interaction regulates virus-specific primary and memory CD8 T cell response. PLoS Pathog. 6:e1000882.

Stock, P., T. Kallinich, O. Akbari, D. Quarcoo, K. Gerhold, U. Wahn, D. T. Umetsu, and E. Hamelmann. 2004. CD8(+) T cells regulate immune responses in a murine model of allergen-induced sensitization and airway inflammation. Eur. J. Immunol. 34:1817-1827.

Stojadinovic, M., R. Pieters, J. Smit, and T. C. Velickovic. 2014 Cross-linking of beta-lactoglobulin enhances allergic sensitization through changes in cellular uptake and processing. Toxicol. Sci. 140:224-235.

Świątecka, D., L. H. Markiewicz, and B. Wróblewska. 2013. In vitro evaluation of the effect of the buckwheat protein hydrolysate on bacterial adhesion, physiology and cytokine secretion of Caco-2 cells. Cent. Eur. J. Immunol. 38:317-327.

Taniguchi, Y., N. Yoshioka, K. Nakata, T. Nishizawa, H. Inagawa, C. Kohchi, and G. I. Soma. 2009. Mechanism for maintaining homeostasis in the immune system of the intestine. Anticancer Res. 29:4855-4860

Tasnim, U. T., and M. T. Islam. 2015. Pathogenic and drug resistant bacteria in raw milk of Jessore city: A potential food safety threat. Bangl. J. Vet. Med. 13:71-78.

Thang, C. L., J. I. Boye, and X. Zhao. 2013. Low doses of allergen and probiotic supplementation separately or in combination alleviate allergic reactions to cow $\beta$-lactoglobulin in mice. J. Nutr. 143:136-141.

Vahjen, W., D. Taras, and O. Simon. 2007. Effect of the probiotic Enterococcus faecium NCIMB10415 on cell numbers of total Enterococcus spp., E. faecium and E. faecalis in the intestine of piglets. Curr. Issues Intest. Microbiol. 8:1-7.

Van Kampen, C., J. Gauldie, and S. M. Collins. 2005. Proinflammatory properties of IL-4 in the intestinal microenvironment. Am. J. Physiol. Gastrointest. Liver Physiol. 288:G111-G117.

Vordenbäumen, S., T. Saenger, A. Braukmann, T. Tahan, E. Bleck, J. Jose, and M. Schneider. 2016. Human casein alpha s1 induces proinflammatory cytokine expression in monocytic cells by TLR4 signaling. Mol. Nutr. Food Res. 60:1079-1089. 